8-1-2004

\title{
Two Early Codes, The Ten Commandments and the Twelve Tables: Causes and Consequences
}

\author{
Alan Watson \\ University of Georgia School of Law, wawatson@uga.edu
}

p bepress $S$ TSR

\section{Repository Citation}

Alan Watson, Two Early Codes, The Ten Commandments and the Twelve Tables: Causes and Consequences (2004),

Available at: https://digitalcommons.law.uga.edu/fac_artchop/651

This Article is brought to you for free and open access by the Faculty Scholarship at Digital Commons @ University of Georgia School of Law. It has been accepted for inclusion in Scholarly Works by an authorized administrator of Digital Commons @ University of Georgia School of Law. Please share how you have benefited from this access For more information, please contact tstriepe@uga.edu. 


\title{
Two Early Codes, the Ten Commandments and the Twelve Tables: Causes and Consequences
}

\author{
ALAN WATSON
}

That title of this talk might suggest that I will speak of two bodies of law separately. Not entirely correct. And that I will speak of them on the same level. False.

The world has known four sources of law: legislation, ${ }^{1}$ judicial precedent, juristic opinion, custom. They do not always, or perhaps ever, exist together in the same place at the same time.

The core of law is authority. Law must be authoritative and be authoritarian. If law is not observed, at least to some degree, it is not worthy of the name of law. ${ }^{2}$ But then it has seemed rather strange to me in the past that a lesson of history is that, overall, governments are little interested in legislating much in many areas.

The lesson of history, in fact, is that over most of the field of law, and especially of private law, in most political and economic circumstances, political rulers need have no interest in determining what the rules of law are or should be (provided always, of course, that revenues roll in and that the public peace is kept). Rulers and their immediate underlings can be, and often have been and are, indifferent to the nature of the legal rules in operation. ${ }^{3}$

Even when great legislators like Justinian, Napoleon or Atatürk appear, they often show little interest in giving their legislation a precise social, religious or economic slant. ${ }^{4}$ For instance, in fiercely Christian early Byzantium, in the body of Justinian's elementary textbook, the Institutes, and in his huge collection of juristic rules, the Digest, Jesus is not mentioned, nor are apostles, nor even the opinions of the Fathers of the Church. Not only that, but the Digest of 533 scarcely contains law later than $235 .^{5}$ Atatürk's civil code for 
Turkey of 1926, Türk Kanипnи Medesini, is little more than a translation of the old Swiss civil code. Moreover, great legislators like Justinian are at times remarkably indifferent to communicating the substance of the law. Thus, for first year law students his account of civil procedure in $J$. book 4 is largely incomprehensible, and his great Corpus Iuris Civilis is overwhelmingly in Latin, a language not fully comprehensible to the majority even of his educated subjects. Yet the Corpus Iuris is the most highly prized and influential of all Western collections of legislation. Similarly, since at least the sixteenth century and right up to today scholars have stressed the difficulty of finding the law in English statutes. ${ }^{6}$

Law needs authority to be authoritative. For judicial precedent, juristic opinion, custom to be law requires acquiescence in the decision by the ruler. But there is more to the issue. Thus, 'good' jurists have to decide according to the reasoning approved by their fellow jurists, judges by top legal figures. In a customary system a supposed custom has to be found. This authority has to be discovered or invented and this need is one of the main causes of legal borrowing, no matter which sources of law are used. Likewise, the need for authority is the cause of the continuance of much dysfunctional law. The need for authority bends law out of shape.

Rulers are content usually to allow others to make the law. Legislation is the sole source of law that is directly under the control of the ruler. The sole necessary talent of rulers is to remain in power. It is this that accounts for the general neglect of many areas of law by legislators. Most of the time most areas of private law, and even criminal law, will be irrelevant for their survival. It is not necessary for rulers to strive to give their society the best or most suitable law. Legislation is predominantly, if not always wholly, political. I may mention in passing, American legislators addiction to 'pork'. Other means are found to develop private law.

This last statement holds true even when the law looks apolitical. A good example is the Roman Twelve Tables of around 451/450 BC. This contains almost entirely private law. No provision deals with public offices, and only one concerns the state religion. That last is particularly revealing because it is concerned with a purely secular matter: a woman who becomes a Vestal Virgin is released from paternal power. The absence of religion becomes especially noticeable when we compare the Twelve Tables with the Ten Commandments. When we look at the background to the Tables, the picture becomes clear. For many years there had been a conflict between the plebeians and the patrician elite who had a monopoly of state offices including state priesthoods. The plebeians wanted the right to share in these offices, to be able to know what the law was, and to be equal before the law. The patricians agreed to a code of law provided they drafted it. In the event, the plebeians got none of their demands. The patricians retained their monopoly of offices, the 
code contains only the private law that the patricians were willing to share with the plebeians, and the plebeians still could not know the law because the Twelve Tables did not contain the forms of action. No public or religious law! The code, designed to look like a compromise or even a defeat, was a great victory for the ruling elite. ${ }^{7}$ Their aim was to remain in control. Another example might be Atatürk's reform of Turkish private, commercial and criminal law in 1926. The main incentive was purely political: the need after World War I for a peace treaty with the victorious Allies who demanded modernization of Turkish law. ${ }^{8}$

The Ten Commandments are beyond doubt the most celebrated collection of laws in the Western world. They also have a very high approval rating for their quality. Yet they are extremely peculiar. I believe it is possible to understand them better if we approach them from the general understanding of lawmaking that I have just sketched. But first I must set out some of the obstacles to our comprehension.

There is widespread but not universal scholarly opinion that they are not the work of Moses. ${ }^{9}$ But then there is no agreement as to the precise dating of the laws or the historical circumstances in which they were made. Or even if they were originally laws at all. It is by no means certain that they were the work of one leader at one time. It can be plausibly argued that they are a collection from various materials and were never established at one time. If so, can one reasonably talk of a common purpose? Again, in Exodus the account of them is immediately followed by judicial laws and by ceremonial laws, both ostensibly given to the Israelites by God through Moses. Should we see the Ten Commandments as one part of a trilogy? Again a rather different version of their origin is given in Deuteronomy. What are we to make of this?

My approach will be to assume that there were standard - more than one, but connected - traditions about God giving laws to the Israelites. These traditions were formed into the accounts in Exodus and Deuteronomy. Those responsible for the final version of the traditions made choices, but they were limited in their options by the traditions themselves.

On this basis, I will treat the Ten Commandments in Exodus as a unit ignoring for the time being the judicial and ceremonial laws. I will not be concerned with the historical accuracy of God delivering the laws to Moses. My concern will be with the nature of the tradition. Historical or not, the tradition should reveal much for the understanding of the factors in law-making, not only of the belief of the redactor, but also of the people from whom it derived and for whom it was intended.

On this basis I wish to address some of the peculiarities of the Commandments. The relevant passages of Exodus 20 read: 
1. Then God spoke all these words:

2. I am the Lord your God, who brought you out of the land of Egypt, out of the house of slavery;

3. you shall have no other gods before me.

4. You shall not make for yourself an idol, whether in the form of anything that is in heaven above, or that is on the earth beneath, or that is in the water under the earth.

5. You shall not bow down to them or worship them; for I the Lord your God am a jealous God, punishing children for the iniquity of parents, to the third and the fourth generation of those who reject me,

6. but showing steadfast love to the thousandth generation of those who love me and keep my commandments.

7. You shall not make wrongful use of the name of the Lord your God, for the Lord will not acquit anyone who misuses his name.

8. Remember the Sabbath day, and keep it holy.

9. Six days you shall labor and do all your work.

10. But the seventh day is a Sabbath to the Lord your God; you shall not do any work - you, your son or your daughter, your male or female slave, your livestock, or the alien resident in your towns. ${ }^{10}$

11. For in six days the Lord made heaven and earth, the sea, and all that is in them, but rested the seventh day; therefore the Lord blessed the Sabbath day and consecrated it.

12. Honour your father and your mother, so that your days may be long in the land that the Lord your God is giving you.

13. You shall not murder.

14. You shall not commit adultery.

15. You shall not steal.

16. You shall not bear false witness against your neighbour.

17. You shall not covet your neighbour's house; you shall not covet your neighbour's wife, or male or female slave, or ox, or donkey, or anything that belongs to your neighbour. ${ }^{11}$

A first peculiarity to notice is that the provisions are remarkably nonthreatening. A glance at other ancient codes or laws will show the difference. Thus, the first section of the Code (or Laws) of Hammurabi (of, at the latest, the early seventeenth century BC) reads: 'If a man has made allegations against another man, and he has laid a charge of homicide against him but is unable to substantiate his guilt, the one who made the allegations against him shall be killed. ${ }^{12}$ In contrast, penalties are noticeably absent from the Ten Commandments. Mention of punishment occurs only in three, two of them among the religious rules, and they are non-specific. Thus, for bowing down to other gods, God will punish the children for the offence of their 
parents down to the fourth generation (20.6). The precise punishment, however horrible it might be, is not expressed. For wrongly using the name of God He will not acquit (20.7). The remaining mention of punishment scarcely deserves that name: you should honour your parents 'so that your days may be long in the land that God is giving you' (20.12).

The provision on honouring parents might be regarded as transitional. The rule of human kindness is interpersonal, but the 'penalty' involves God. It might be suggested, moreover, that this 'penalty' is a much later addition: as such it does not appear in the corresponding text of Deuteronomy 5:16: 'Honour your father and your mother, as the Lord your God commanded you, so that your days may be long and that it may go well with you in the land that the Lord your God is giving you.'

Again the Commandments are split into two very distinctive parts: behaviour towards God, behaviour towards other humans. And the parts are distinctly unequal. Duties towards God are much more prominent. It is not just that these rules come first. They are much more detailed. For example, prohibitions against work on the Sabbath are spelled out to apply not only to the male head of the family, but also to his sons, daughters, male slaves, female slaves, even his animals and visitors. In contrast, for inter-human law we have, for instance, simply 'you shall not kill'. There is a translation difficulty: 'kill' or 'murder'? ${ }^{13}$ No matter for the moment. Not only is the penalty not set out, but the offence is not defined or described. Yet the offence cries out for clarification.

But there is much more. The rules about behaviour to other humans are socially necessary but banal in the extreme: no murder, no theft, no adultery, no false witness. Why did God bother with these? Why was He needed? Not even the penalty is spelled out.

Then the two interpersonal commands that are not just framed 'You shall not__ ' are framed in a more complex manner. Thus, a reason for honouring father and mother is given, and it scarcely seems to have a legal content. ${ }^{14}$ It is also expressed more directly: 'Honour___'. The last command, 'You shall not covet_— ', concerns mental activity, not physical action, and can scarcely give rise to a lawsuit. And there is a third peculiarity in the tradition - though this time not in the substance of the Commandments - in the role of Aaron. And Aaron's role is pivotal.

These peculiarities in the tradition must be explained and, for me, the explanation must lie within the tradition itself.

[I am well aware that some readers will reject this paper as giving too few references to standard scholarship. I understand. But my concerns are not with the precise meaning of individual provisions, nor with the historical provenance of our accounts in Exodus and Deuteronomy, nor even with 
Deuteronomy. All I set out to do is to understand the tradition in Exodus in the context of the place of legislation in the history of legal development]. ${ }^{15}$

Legislation is a very particular form of law-making - the only source of law that rulers keep under their direct control. And the only necessary talent of rulers is to remain in power. Moses is a leader in trouble. Indeed, for him, one problem follows another. It was God who appointed Moses as the Israelites' leader, and who performed miracle after miracle to keep Moses in power. Defeat for Moses would be defeat for God. And Moses always had a prospective rival in the wings, his elder brother Aaron. Aaron is prominent in Moses' leadership from the very beginning, and is also a leading figure in the Israelites' rebellion against God, in the making of the golden calf. Just before God gave the Commandments to Moses his sympathetic father-in-law told Moses he was wearing himself out in deciding lawsuits. Moses has to keep his authority and God's authority. Legislation is his solution. God is Moses' authority, and the legislation must stress God's authority for the Israelites. The control of legal relations between humans is of little concern. These can be dealt with by lower officials.

Moses murdered an Egyptian and fled to Midian (2.11 ff.). God appeared to Moses and told him He would send him to Pharaoh to deliver the Israelites from bondage (3.7 f.). Moses protested, but God insisted (3.11 ff.). God emphasized that the Egyptian king would not let them go, but that $\mathrm{He}$ would smite the Egyptians, and the Israelites would be allowed to leave (3.19 ff.). Moses continued to protest and God showed him miracles (4.1 ff.). Moses continued to protest, claiming that he lacked eloquence (4.10 ff.). God was angered and replied that his brother Aaron (who was coming to meet Moses) had fluency and would act as his mouthpiece (4.14 ff.). ' $\mathrm{He}$ indeed shall speak for you to the people: he shall serve as a mouth for you, and you shall serve as God for him' (4.17). ${ }^{16}$ Moses left for Egypt with his wife and sons (4.18 ff.). God told Aaron to meet Moses, and Moses told Aaron of God's miracles and what He had said (4.27 f.). Moses and Aaron assembled the Israelite elders (4.29). "Aaron spoke all the words that the Lord had spoken to Moses, and performed the signs in the sight of the people' (4.30). The people believed (4.31). Moses and Aaron went to Pharaoh and told him God wanted them to celebrate a festival in the wilderness (5.1 ff.). But Pharaoh answered: 'Moses and Aaron, why are you taking the people away from their work? Get to your labours' (5.5). Note that Moses and Aaron are treated as equals before Pharaoh. Pharaoh increased the workload of the Israelites who blamed Moses and Aaron (5.20 ff.). God spoke to Moses, promising freedom (6.1 ff.). 'Moses told this to the Israelites: but they would not listen to Moses, because of their broken spirit and their cruel slavery' (6.9). God told Moses to tell Pharaoh to let the people go, but Moses protested that Pharaoh would not listen because he was a poor 
speaker (6.10 ff.). God then gave Moses and Aaron His orders (6.13). We are again told that God ordered Moses and Aaron to bring the people out of Egypt (6.26), and they spoke again to Pharaoh (6.27). God spoke again to Moses who again protested he was a poor speaker, and that Pharaoh would not listen. God said 'See I have made you like God to Pharaoh, and your brother Aaron shall be your prophet. You shall speak all that I command you, and your brother Aaron shall tell Pharaoh to let the Israelites go out of his land' (7.1 f). Then comes the biblical treatment of the ten plagues inflicted upon Pharaoh by God for failing to let the Israelites leave (7.14-12.32).

The chapters reveal a fascinating dichotomy. God speaks primarily to Moses, with Aaron very much Moses' helpmeet. Yet Moses' weakness is stressed. In contrast, in their interaction with Pharaoh Moses and Aaron appear very much on the same level. If we can assume, as I believe is reasonable, that when Moses and Aaron were before Pharaoh and his officials members of the Israelite elite were also present or at least knew of the meeting, and Aaron would be regarded by them as very close to being Moses' equal.

But a side issue then arises. If God can work so many miracles, why does He leave Moses with such a defect that he needs Aaron's constant help? The issue, I think, is significant.

While the Israelites were still in Egypt, God gave Moses and Aaron instructions for the first Passover (12.1 ff.), but it is Moses who communicated them to the Israelites (12.21 ff.). Yet again, God gave Passover instructions to both Moses and Aaron (12.43 ff.). And the people followed their instructions (12.50). God told Moses to consecrate all the firstborn to Him (13.1 f) and Moses did so. In these fundamental legal matters Moses is basically his own spokesman.

God told Moses to camp before the Red Sea (14.1 ff.); Pharaoh prepared to attack (14.5 ff.), and the people blamed Moses vehemently for what seemed an approaching disaster (14.11 ff.), but, through the agency of Moses, God destroyed the Egyptians (14.15 ff.). The miracle of the Red (or Reed) Sea is the climax of the Exodus, and Aaron is not mentioned. 14.31 records 'So the people feared the Lord and believed in the Lord and in his servant Moses'. According to the tradition in the Passover Haggadah (section 'The Plagues'), the number of plagues inflicted on the Egyptians at the sea was vastly greater than the ten plagues in Egypt.

Later at Marah the water was bitter and could not be drunk and the people blamed Moses (15.23 ff.). In the wilderness the Israelites complained against both Moses and Aaron (16.1 ff.) And God told Moses he would rain manna from Heaven (16.4), and Moses and Aaron gave instructions to the people (16.6 ff.). Moses then told Aaron to say to the people: 'Draw near to the Lord' (16.9). Moses gave further instructions to the people about manna, 
but not all of them obeyed (16.5 ff.). Further on, again the people disobeyed (16.27 ff.). God told Moses that some manna should be placed before the covenant for ever, and Moses so instructed Aaron (16.31 ff.). The people quarrelled with Moses because they had no water, and Moses told God that the people were almost ready to stone him. God told Moses to strike a rock with his staff and water came forth (17.1 ff.). God enabled Moses, with the help of Aaron and Hur, to defeat Amalek (17.8 ff.).

Again a clear pattern emerges. God had chosen Moses to be the leader of the Israelites. For God, Aaron is definitely Moses' subordinate, and Aaron acted as Moses' intermediary with the people. Time and again God saved the Israelites in distress with a miracle performed through Moses. Yet time and again, when the people were in distress they quarrelled with Moses. Despite his authority from God, Moses did not have the confidence of his people. His control was shaky.

Perhaps more immediately in the present context, Moses was wearing himself out with hearing lawsuits all day long. His father-in-law had come for a visit, saw Moses judging all day, wearing himself out (18.13), and he advised him to teach the people the statutes and instructions. He also advised that Moses should appoint judges to hear minor cases, but should hear major cases himself. Moses agreed. He summoned the people and they agreed to do whatever God said (19.7). Shortly thereafter, God delivered the Ten Commandments. Thus, a leader in trouble received authoritative legislation.

I need not record the steps by which God ensured that only Moses would see Him and speak with Him (19.9 ff.). Nor is it important to discuss the laws that God subsequently gave orally to Moses (20.22-40.38). Whether they come from a different time in history need not concern us. But three points about them should be mentioned:

First, the rules on behaviour between humans do not confirm the widely held view that the Ten Commandments cover all the law in short compass. ${ }^{17}$ The Commandments contain nothing about slavery, violence less than murder, the law of torts and restitution; all these are matters treated in the Book of the Covenant. These rules in the Book of the Covenant again indicate the lack of interest in 'secular' law in the Commandments.

Second, the rules on religious ceremonial matters are very much more detailed than those on interpersonal law. Again the authority of God and the importance of reverence towards Him are stressed. They are of supreme importance to Moses as leader.

Third, much is made of Aaron and his sons being appointed priests, their vestments, the ephod, and of a splendid breastplate for Aaron, other priestly vestments for the sons and their ordination, their tending of the lamp (27.20-29.46). God, or Moses, needs to keep Aaron loyal to the service of 
God, and hence to Moses. (It may be worth noting that rabbinic tradition emphasizes that Moses and Aaron were of equal worth). ${ }^{18}$

A little more should be said about the distinction made between the Ten Commandments and the judicial and ceremonial laws which existed - as Philo shows - as early as the time of Jesus. The Ten Commandments, it is claimed, were addressed to all, the other laws only to the Jews. Not so. The Ten Commandments are expressly addressed to the Jews. Exodus 20.2 reads: 'I am the Lord your God who brought you of out the land of Egypt'. A further distinction often drawn is that God gave the Ten Commandments directly, the other laws were mediated through Moses. This distinction seems arbitrary. The real difference seems to me that the ceremonial and judicial laws could never be acceptable outside of a small Jewish section.

When Moses descended from Mount Sinai the worst had happened (32.1 ff.). The Israelites had made a golden calf, a new god, who was asserted to have brought them out of Egypt (32.4). Thus, God was denied, and so was Moses' authority. Aaron is not reported to be the ringleader of the revolt, but only as much involved from the start. The people said to Aaron: 'Come, make gods for us, who shall go before us' (32.1). Aaron's reported response was: 'Take off the gold rings that are on the ears of your wives, your sons, and your daughters, and bring them to me' (32.2). Aaron actually made the calf-god (32.4) and instituted a festival for it (32.5 f).

At this point I would like to respond to a friendly criticism from a Christian fundamentalist who believes God did give the Ten Commandments to Moses. He says with respect to the final Commandment: 'God, but not man, would care about coveting'. ${ }^{19}$ I disagree. Moses, a leader in trouble, has supreme interest in coveting. His job! It is at risk. The subsequent behaviour of Aaron is revealing. Aaron has not yet made his move, but he will. No one should underestimate the vigour with which political figures protect their jobs. I can understand that God might oppose coveting but I see no compelling reason for Him to legislate. But in the tradition Moses has a strong positive interest.

Another point should be made. The prohibition against coveting makes superfluous the rules against stealing and adultery. Both involve coveting. ${ }^{20}$

My conclusions about the history of the tradition behind the Ten Commandments in Exodus are as follows:

(1) Of the four sources of law only legislation is under the direct control of governments.

(2) The lesson of history is that in general most governments at most times are little interested in legislating in many areas of law.

(3) The sole necessary talent of governments and rulers is remaining in power. Hence the paucity of legislation in many areas of law. Rulers have better things to do (for themselves) with their time. 
(4) Legislation is accordingly always or usually political: its raison d'être is to keep the government in power.

(5) According to the tradition of Exodus, the Ten Commandments are no exception.

(6) Moses became leader of the Israelites, who were under the subjugation of the Egyptians, on the basis that he was elected by God. Moses, we are told, was reluctant to accept the office, because of his lack of fluency in speech, but God insisted and appointed Moses' brother Aaron to be his helpmeet.

(7) Moses' authority before the people was based precisely on the belief that he was the elect of God.

(8) Through miracles of God Moses did obtain the Israelites' release from slavery in Egypt.

(9) Moses' authority continued to rest on his unique position from God. Whereas God kept Aaron in a clearly subordinate position, Aaron's status among the Israelites seems, in contrast, almost like that of Moses.

(10) When great hardships befell the Israelites during the Exodus they continually blamed Moses for their plight. This inevitably entails a diminution of faith in or respect for God on whose authority Moses' power depended. Aaron was less criticized. Despite God's miracles the Israelites repeatedly showed a lack of confidence in Moses' leadership, and hence in God. Moses' authority was under siege. Hence, he could not afford to seem too threatening.

(11) Moses was under great strain not only from this but also because he was spending his days in judging. A solution was proposed by his father-in-law, significantly not an Israelite but a Midianite.

(12) God intervened, and provided laws for the Israelites but under specific circumstances: (a) the people were told that God would legislate with no input from the people, (b) the laws were given directly by God to Moses, but to no one else, (c) indeed, God was to be absolutely hidden to others.

(13) As is to be expected, if my first four conclusions are correct, the laws of God very much bolstered the authority of Moses. The stress is precisely on religious laws, hence on the authority of God, hence on the authority of Moses. Laws with a secular impact were little considered. This is why they are banal.

(14) The people were still not impressed by Moses' leadership and during his absence on Mount Sinai they worshipped as god a golden calf, thus attacking God's first Commandment (which they still did not have), hence God's authority and thus Moses' authority.

(15) If not the instigator, Aaron, the second in command, was prominent in the revolt, even suggesting where to obtain the material for the calf and 
making it. As often, the second-in-command is eager for the leading role. In Exodus the talent of Aaron is presented above all as the power of persuasion. Given that fact, it seems plausible that at one stage in the tradition (now unrecorded) Aaron appeared as the instigator of the revolt. As often in history, then, Moses would have co-opted Aaron, and used him against his followers.

(16) Thus God had been eager to encourage or placate Aaron by giving favours. In vain. (Aaron's resentment against Moses is brought up very sharply in Numbers 12. It is part of the tradition. God weighs in in favour of Moses.)

(17) Moses ultimately triumphed through the power of God. Aaron easily submitted to him.

(18) The role of Aaron is essential to the tradition. Moses must have weaknesses for the story to unfold. He must have a helpmeet. Moses must have great problems with the people, and the people must have an alternative power-figure. For the authority of God fully to emerge this figure must in the end fail miserably.

I will not dwell here on the subsequent history of the Ten Commandments ripped out of context. It is enough to note that 'Honour your father and mother' survives in the French code civil of 1804, art. 371, though it has almost never been applied, and the reason given for it has disappeared. The debate over the placing of the Commandments in US court houses continues to this day.

To come at last to the Roman Twelve Tables. I have already given a sketch of how they came into being. Here I want to deal only with one institution of the code, mancipatio, which existed long before but which is dealt with in Tab. 7.6 ff. dealing with praedial servitudes; Tab. 5.3 dealing with succession; Tab. 4.26 dealing with the sale of a son.

I have two points to make. The ingenuity of jurists in developing law in the absence of further legislation. And the difficulty of outsiders in grasping what was going on. The consequences of starting points are enormous and unforeseen. The example I have chosen is mancipatio. Its form for the classical period is described by Gaius in his Institutes, 1.119:

Now mancipatio is, as we said above, a sort of imaginary sale, and it, too, is peculiar to Roman citizens. It is performed thus: not fewer than five witnesses who are Roman citizens above puberty plus one other who holds a bronze scale and is called a libripens, are summoned and brought together, and the person who takes by the mancipatio, 
holding the bronze, speaks thus: 'I declare this man is mine by the law of the citizens, and let him have been bought by me by this bronze and this bronze scale'. Then he strikes the scale with the bronze and gives the bronze, as if in the place of the price, to the person from whom he is receiving in mancipatio.

In G.1.121, Gaius tells us that the object to be mancipated must be present, unless it is land, which is regularly mancipated at a distance. The ceremony, whose antiquity is well attested, obviously derives from an actual sale before the time of coined money, when copper or bronze as the price was actually weighed on the scale. Which things were res mancipi in Gaius' time are explained by him in G.2.14a-17:

14a. There is also another division of things: for they are either res mancipi or res nec mancipi. Res mancipi are land and houses on Italic soil, likewise slaves and those animals that are usually broken to draft or burden, such as cattle, horses, mules, and asses: likewise rustic praedial servitudes. For urban praedial servitudes are nec mancipi. Nec mancipi are also stipendiary or tributary lands. 15. A question is raised as to the meaning of our statement that those animals that are usually broken in are res mancipi, because they are not broken in at the time of birth. And the leaders of our school think they are res mancipi as soon as they are born. But Nerva and Proculus and other leaders of the other school hold that they do not become res mancipi unless they are broken in and if, because of too much wildness, they cannot be broken in then they come to be res mancipi when they reach the age at which they usually are broken in. 16. Likewise wild beasts are res nec mancipi, such as bears, lions, likewise these animals which are almost in the category of wild animals, such as elephants and camels; and it does not matter that these animals too are broken in to draft or burden, for their very names did not exist in the time when it was settled which things were res mancipi and res nec mancipi. 17. Also, nec mancipi are almost all incorporeal things, with the exception of rustic praedial servitudes, which, it is settled, are mancipi although they are in the category of incorporeal things.

Three peculiarities in the list may help to establish the original list of res mancipi and explain the classification. First is the dispute between the Sabinians and the Proculians over cattle, horses, mules and asses, the Sabinians including all such, the Proculians only those broken in or of the age at which they were usually broken in. Second is the inclusion of land, which is thought not to fit particularly well into the ceremony, since it involves a grasping by the hand. ${ }^{21}$ Third is the inclusion of rustic praedial servitudes, 
which were incorporeal rights and did not involve (in classical law at least) the legal right of ownership. A fourth peculiarity - much discussed by scholars is less obvious at first sight: the inclusion of horses may be odd, since unlike the other animals classified as res mancipi, horses were not much used for agricultural work. ${ }^{22}$ Until the invention much later of the horse collar, horses had little pulling power. A further, revealing, point appears incidentally. Gaius shows that the classification has no surviving rational value. Elephants and camels are not res mancipi, not because they lack the characteristics of the objects of that class, but because they were not known when the classification became fixed. Gaius betrays no disquiet at this lack of fit. This is in the tradition of legal development.

The remote origins of the classification probably cannot be determined. It may be that originally there was no rigid distinction between res mancipi and other things: there was only the feeling that, for greater security, important things should be transferred before witnesses. What these things were gradually became fixed, as did the details of the required ceremony. An alternative thesis might be that some things were conceived of as being more 'family' property than other things ${ }^{23}$ and were at first inalienable or (both at first and later) alienable only publicly. In either eventuality, slaves, horses, cattle, asses and mules are an obvious unit. Greater precision is not needed here.

Italic land is also classified as res mancipi along with these animate beings, though it is (to us) obviously different in nature. Whether or not it was always so classified - perhaps, not, if, as is sometimes claimed, land in early times was not in private ownership - cannot, I think, be established, but the application to it of the ceremony of mancipatio is our first glimpse of pragmatism in this context. Mancipatio, as a ceremony, involved in its developed form a grasping in the hand that is not entirely appropriate for land. One may conclude either that land was added to the list of res mancipi after the form of the ceremony was fixed, or that as the class of res mancipi emerged and as the details of the form of transfer were recognized as necessary, one ceremony alone became acceptable for the transfer of all res mancipi, though it was not always wholly appropriate. In either case, it was opportunistic either to classify land as res mancipi or to treat mancipatio as appropriate to it.

But a much more flagrant case of opportunism appears in the classification of rustic praedial servitudes as res mancipi. ${ }^{24}$ The four original praedial servitudes were iter, a right of passage, actus, a right of driving beasts, via, a right of having a 'paved' road, and aquae ductus, a right of aqueduct. These servitudes or easements are of extreme economic importance in a primitive agricultural community. Farming neighbours will obviously want to make use of them, and they will come into existence in practice by consent, even without legal recognition. But nonetheless the need for legal protection will soon be felt. How are neighbours to create such rights? Some form will be 
needed. In the absence of official intervention, recourse could be had to the ceremony of mancipatio. ${ }^{25}$ Traditio (delivery), the standard method of conveying res nec mancipi, could not be used, not just because of its informality but also because it required physical delivery of the thing to be transferred. ${ }^{26}$ There is no alternative to mancipatio. And eventually the courts will recognize that servitudes have been created. A purely pragmatic solution was found. But, as a consequence, praedial servitudes, though incorporeal rights, were classified as res mancipi.

Failure to appreciate Roman legal pragmatism has led scholars to hold that the early Romans and their successors for a long time conceived of servitudes as corporeal objects, and that the holder of the servitude right had ownership of the corresponding strip of land, or alternatively that ownership of the strip of land was functionally divided between the owner of the land and the neighbour in right of the servitude. ${ }^{27}$ Diósdi has given the conclusive arguments against such views by analyzing two provisions of the Twelve Tables. One provides that the owner of the land must lay a road, via, with stones (or, alternatively, set curbstones), and if he does not, the other may drive his beast wherever he wants. ${ }^{28}$ As Diósdi says, if the person entitled to passage had become the owner of the strip of land, the owner of the servient land would be under no obligation to pave it, nor if the owner failed to do so, would the other be able to lead his beast where he wished. ${ }^{29}$ The other provision is even more to the point and declares that the breadth of the via should be eight feet on the straight, sixteen feet on the bends. ${ }^{30}$ This provision, as Diósdi claims, would have been superfluous if via gave ownership, since the transfer itself would then define the territory. ${ }^{31}$ It should be stressed that it is the fact that mancipatio is used to create servitudes that has led modern scholars to claim that servitudes were considered by the early Romans to be corporeal things. Strong is the belief that law is rational.

Mancipatio, with a variant wording for the nature of the taking - akin to fide et fiduciae ('to my faith and trust') - was used to create real security of res mancipi. ${ }^{32}$ The creditor accepted ownership of the pledged property, and, since as owner his security was great, he could allow the debtor to continue to possess and use the pledged property. The usage was a benefit to both.

But the Romans came to use the ceremony of mancipatio very creatively well outside the realm of the transfer of res mancipi. One variation was to permit in early law the making of a will, the so-called testamentum per aes et libram. This is described by the jurist Gaius in the mid-second century ad, in his Institutes 2.104:

The proceedings are as follows: the person making the will, as in other mancipations, takes five Roman citizens above puberty as witnesses and a balance-holder and, after having written his will, mancipates his 
familia [i.e., his property considered as a unit]. ${ }^{33}$ In the mancipatio, the recipient of the familia uses these words: 'I declare your familia and your property to be subject to your instructions under my guardianship so that you may lawfully make a will according to the public statute, and let it have been bought by me with this bronze (and some add) with this bronze scale'. Then he strikes the balance with the bronze and gives the bronze to the testator as if in lieu of the price. Then the testator, holding the tablets of the will, says: 'As it is written on these tablets and in this will, so I give, so I legate, so I call to witness, and so, citizens, do you bear me witness'. This is called nuncupatio, nuncupare meaning to declare publicly. And by these general words the testator is thought to declare and confirm what he had specifically written in the tablets of the will.

By the second century BC (and indeed, long before), this testamentum per aes et libram, as it is called, had become a proper will in which an heir could be appointed. This was not the original position. In early Rome before the Twelve Tables, a will could be made publicly before the assembly known as the comitia calata, which met twice a year, on 24 March and 24 May, for the purpose of making wills. This was obviously very inconvenient, and the practice grew up of making testamentary dispositions by using a modified form of mancipatio. This practice was confirmed by the Twelve Tables in a provision (Tab. 5.3) that apparently read something like: Uti legassit super pecunia tutelave suae rei, ita ius esto ${ }^{34}$ ('As he made a legacy over his property [pecunia] and the guardianship of goods, so let the law be'). The provision talks of legating, not of appointing an heir; the word pecunia (property) does not have, as familia has, the implication of property treated as a unit, and it would thus seem that at that time this type of testamentary disposition did not extend, as it did later, to the appointment of the heir entitled to the estate. ${ }^{35}$

Although no heir could thus be appointed at the time of the Twelve Tables, this is, nonetheless, a very creative use of mancipatio. This variant mancipatio could be used to appoint a tutor under the will, a result very different from transferring res mancipi, and to transfer res nec mancipi. The variant shows that the wording of mancipatio was not absolutely fixed and that no real weighing out of copper had to be involved. There is no evidence that the familiae emptor ever acquired any rights or duties as a result of the ceremony, ${ }^{36}$ and the legatee became the owner automatically on the testator's death. Thus the ceremony did not immediately transfer even res mancipi at the moment it was performed. This use seems to have been the result of private initiative, hence the clause confirming its legal effectiveness in the Twelve Tables. 
But scholars seem to have difficulty in accepting the opportunism involved in this kind of development. Max Kaser talks in terms of a divided ownership between the testator and the familiae emptor and subsequently between the familiae emptor and the legatees. ${ }^{37}$ None of this is justified by the sources, and such an explanation is needed only if one takes a formalistic attitude to legal development.

A further use of mancipatio was in marriage (G.1.113): 'By coemptio women come into manus (matrimonial power) by mancipatio, that is by a sort of imaginary sale; thus, in the presence of not fewer than five Roman citizen witnesses above puberty, he into whose manus she comes, buys the woman' ${ }^{38}$ In early Rome, marriage was either cum manu or sine manu. The former put the wife into the family and under the power of the husband, or of his paterfamilias if he had one. The latter left her in her family, or in her own control, sui iuris. Coemptio was one of the major ways of putting the wife into the manus of her husband, and it existed from an early date. Whether coemptio originally was a true sale cannot be established. Certainly one can draw no argument from the fact that the ceremony involved the appearance of a sale, since a similar procedure operated for adoption, which certainly did not involve sale and purchase. In all probability, coemptio was a device to extend marriage cum manu to segments of the population that could not make use of confarreatio for that purpose, since the latter required the presence of some of Rome's highest religious dignitaries and hence was very much confined to the most powerful families.

One easily overlooked detail in coemptio is instructive regarding Roman legal opportunism. There is no indication that coemptio was restricted to situations in which a woman had a paterfamilias, and it would be very surprising if it were. But if the woman were sui iuris, there would be no one to whom the familiae emptor could give the bronze. She would be in the manus of her husband and all her property would belong to him, so she could not be the recipient of the bronze. The innovative Romans were unlikely to have wasted time on such an unimportant technicality.

Closely allied to mancipatio, probably in fact a version of it and certainly an act per aes et libram, was nexum, by which a free man was bound to a creditor and was subject to his control until an amount of bronze that had been paid out was repaid. ${ }^{39}$ Nexum was regulated by the Twelve Tables (Tab. 6.1), and probably in this context also belongs the provision (Tab. 4.2b): Si pater filium ter venum duit, filius a patre liber esto ('If a father sells his son three times, let the son be free from the father'). ${ }^{40}$ If a son was mancipated - that is, given in nexum - three times by his father to work off a debt (or until a loan was repaid), the son would become free from paternal power. This clause came to be used pragmatically to achieve two very different ends. The first was to free a son from paternal 
power (emancipatio) while his father was still alive and thus make the son a pater in his turn. This had numerous advantages for the son, above all in that only a person sui iuris not subject to another's power could own property.

G.1.132: Moreover, children cease to be in paternal power by emancipatio. But a son passes out from paternal power by three mancipations, other descendants whether male or female by one mancipation. For the Twelve Tables speak of three mancipations in the case of the son alone, in these words: 'If a father sells his son three times, let the son be free from the father.' This is the procedure: the father mancipates the son to someone; this last manumits the son vindicta; on that account the son reverts into the potestas of the father. He mancipates him a second time either to the same or another person (but it is customary to mancipate him to the same person), and he afterward similarly manumits him vindicta again; and thereby he reverts again into the potestas of the father. The father mancipates him a third time either to the same or another person (but it is customary to mancipate him to the same person) and by this mancipatio he ceases to be in the power of the pater even though he has not yet been manumitted but is in the position of a mancipium.

But, of course, the person who received him by mancipatio for the third time would manumit the former son, who now became a paterfamilias in his own right. The interpretation of the Twelve Tables' provision as being restricted to sons, so that other descendants would be free from paternal power after one mancipation, is a minor example of opportunism intended to simplify the procedure.

The second pragmatic use of the Twelve Tables' clause was to permit adoption of a person who was in patria potestas.

G.1.134: Further, fathers cease to have in their potestas those children whom they gave to others in adoption. In the case of a son, if he is given in adoption, three mancipations and two intervening manumissions are used, and they are accomplished in the same way as when a father is releasing him from potestas in order to make him sui iuris. Then either he is remancipated to the father and it is from the father that the adopter claims him as his son in front of the praetor, who, with the father making no counterclaim, adjudges the son to the claimant; or he is not remancipated to the father but the adopter claims him from the person with whom he is under the third mancipation. But remancipation to the father is more convenient. For other descendants whether of the male or female sex one mancipation is enough 
and either they are or are not remancipated to the father. In the provinces the same proceedings are used before the governor of the province.

We still have not finished with the opportunistic use made by the Romans of the simple ceremony of mancipatio. One further example may be adduced. Throughout the classical period, ${ }^{41}$ a Roman woman who was sui iuris was subject to perpetual tutelage and required the authority of her tutor for various acts. But if she wished a more complaisant tutor, she could, as Gaius tells us (G.1.115), give herself in coemptio with the consent of her tutor, not for the purpose of marriage. The recipient would remancipate her to the person of her choice, whereupon, after being manumitted vindicta by him, she would come by matter of law under his tutelage. Until the time of Hadrian, this procedure had a particular advantage, since a woman who had not undergone capitis deminutio, or change of civil status, could not make a will. $^{42}$

G.1.115a: Formerly, too, fiduciary coemptio was used for the purpose of making a will. For at that time women, with certain exceptions, did not have the right of making wills, unless they had made coemptio and had been remancipated and manumitted. But the senate on the authority of the deified Hadrian remitted the need of making a coemptio.

The uses made of mancipatio represent a splendid success story for legal opportunism. From being a formal, immediate conveyance of certain kinds of things, mancipatio became a way to create and transfer easements, to form a real security, to put a wife into the marital power (manus) of her husband, to adopt, to free a person from paternal power, to make a will under which even a tutor could be appointed, and enable a woman to change her status, with the effect, inter alia, that she could make a will. But such juristic ingenuity needed official acceptance to be successful. Indeed, for some of the situations involved - notably adoption, emancipation and the change of a woman's status - active state participation was required.

Opportunism by jurists can go a considerable way at times towards alleviating defects in official lawmaking. But it also pinpoints a failure by the state authorities to create the law that is wanted. Successful juristic opportunism with economy of means can only proceed out of such a failure. In addition, such successful opportunism shows a readiness on the part of the state authorities to allow others, private individuals at that, to make a considerable part of the private law. Yet the opportunistic uses of mancipatio have profound social and economic effects. The creation of legally recognized rustic praedial servitudes allows land to be used much more efficiently; fiducia has numerous agricultural and commercial advantages; coemptio greatly widens the social range of husbands who have wives in their power; adoption 
allows families that would otherwise become extinct to continue; emancipation greatly increases the number of persons who can own property; the (more or less) free power of testation is of great consequence for families and dynasties, and so even more is the power of testation accorded to women.

The history of mancipatio does not stand alone.

\section{III}

We have looked at two very different ancient bodies of law. Both are representative instances of massive legislation. They are both the result of intensive political pressure, and they reflect this temporary pressure. The leaders are in trouble and they act to remain in power. Moses rules through the authority of God. The Ten Commandments are given by God to Moses. The stress is on the relationship between God and man; laws on inter-human behaviour are banal and insufficient. It might be said the laws in their stress reflect the society but it should be noted that the authority of God was not that secure. The episode of Aaron and the Golden Calf shows that. In contrast, the Roman Twelve Tables are outstandingly secular. No wonder! The plebeians demanded legal equality with the ruling patricians. After years of conflict the patricians agreed to a code of giving equality before the law. They insisted on drafting it. And the code is remarkably egalitarian but it omits all public law and all religious law. The patricians retained all political and priestly offices. The Roman were regarded and regarded themselves as the most religious people, but this does not appear from the Twelve Tables.

Law is mysterious. The causes of legislation and of the parameters of change are not obvious even at the time, and result in gross misunderstanding especially by outsiders in the future. Rules take on a life of their own. No one could have predicted when the rules were issued the impact of the Ten Commandments in the contemporary USA. For the Twelve Tables I stressed a rather different issue, the remarkable expansion of mancipatio which existed even before. Outsiders often fail to take account of legal inventiveness leading to a belief that Romans treated easements as corporeal property and that marriage by coemptio was a real sale of the woman to her husband.

A further consequence of the history behind the code was that the later jurists were interested almost solely in private law, in interpretation but not in systematization and scarcely in law reform. ${ }^{43}$

\section{NOTES}

1. In what follows, whenever possible, I will use 'ruler' and 'government' interchangeably to avoid repetition.

2. See, e.g., H. Kelsen, The Pure Theory of Law, Berkeley, 1967, $10 \mathrm{f} ; 30 \mathrm{ff}$. 
3. A. Watson, Roman Law and Comparative Law, Athens, GA., 1991, 97; The Evolution of Western Private Law, Baltimore, 2001, $1 \mathrm{ff}$.

4. Watson, Roman Law, $98 \mathrm{f}$.

5. See A. Watson, 'Prolegomena to Establishing Pre-Justinianic Texts', 62 Tijdschrift voor Rechtsgeschiedenis (1996), 113 ff.; J.H.A. Lokin, 'The End of an Epoch: Epilegomena to a Century of Interpolation Criticism', Collatio Iuris Romani 1, Amsterdam, 1995, $261 \mathrm{ff}$.

6. See, e.g., the works cited in A. Watson, Sources of Law, Legal Change, and Ambiguity, Philadelphia, 1984, $77 \mathrm{ff}$.

7. See, e.g., A. Watson, The Spirit of Roman Law, Athens, GA, 1995, $34 \mathrm{ff}$.

8. See now E. Örücü, Critical Comparative Law: Considering Paradoxes for Legal Systems in Transition, Deventer, 1999, 80 ff. and the work she cites.

9. For a brief introduction see C.J.H. Wright, 'Ten Commandments', in G.W. Bromiley, ed., The International Standard Bible Encyclopedia, 4, Grand Rapids, 1988, 786 ff.; see also B.S. Childs, The Book of Exodus, Philadelphia, 1974, 385 ff.; R. Yaron, 'The Evolution of Biblical Law', in La formazione del diritto nel Vicino Oriente Antico, Rome, 1988, 77 ff., especially 90 ff.; R. Yaron, 'Social Problems and Policies in the Ancient Near East', in B. Halpern and D.W. Hobson, eds., Law, Politics, and Society in the Ancient Mediterranean World, Sheffield, 1993, $19 \mathrm{ff}$.

$10 . \quad$ Is the omission of the wife significant?

11. The translation is that of the New Revised Standard Version.

12. Translation of M.E.J. Richardson, Hammurabi's Laws, Sheffield, 2000, 41.

13. See, e.g., Childs, Exodus, $419 \mathrm{ff}$.

14. For a convincing explanation of the formulation of this commandment and its position in Exodus immediately before the prohibition on murder, see above all, C. Carmichael, The Spirit of Biblical Law, Athens, GA, 1996, $94 \mathrm{ff}$.

15. It has been suggested to me that the structure is exactly what one should expect if God actually gave the Commandments to Moses. The interpersonal laws would be familiar, and would need no detail. Yet, for me, detail would still be needed - as we find in other ancient legislation - and the sanctions should be set out.

16. At 4.10, Moses says literally that 'he is not a man of words'. It has been suggested that his difficulty was not lack of fluency, but that he was a foreigner in Egypt. But: (1) apart from his stay in Midian he had spent his whole life in Egypt; (2) after his childhood Moses was treated as a son by an Egyptian princess (2.10); (3) in Midian the daughters of Jethro thought he was an Egyptian (2.19); (4) Aaron would have the same problem with speech; (5) Pharoah is reported as speaking Hebrew. Another late version is that as a child Moses burned his tongue with a coal of fire; for sources see L. Ginsberg. The Legends of the Jews 2, Philadelphia, 1923, $272 \mathrm{ff}$.

17. For this view see, e.g., G. Henton Davies, Exodus, London, 1967, $167 \mathrm{ff}$.

18. Shir Ha-shirim Rabbah 4.5. See Ginsberg, Legends 4, 1925, 424 n.152.

19. See, e.g., Childs, Exodus, $425 \mathrm{ff}$.

20. I owe this point to Hilton Bik.

21. See, e.g., H.F. Jolowicz and B. Nicholas, Historical Introduction to the Study of Roman Law, 3rd edn., Cambridge, 1972, 38.

22. See, e.g., P. Vigneron, Le cheval dans l'antiquité gréco-romaine, Nancy, 1968, 139 ff.; K.D. White, Roman Farming, London, 1970, 288 ff. Some uses of horses was, however, made by farmers. See Cato, De agri cultura, 138.

23. See, e.g., P. Bonfante, Corso di diritto romano vol. 2, La proprietà, Rome, 1927, 182; for a different opinion see, e.g., G. Diósdi, Ownership in Ancient and Preclassical Roman Law, Budapest, 1970, $22 \mathrm{ff}$.

24. G.2.14a, 17, 29; Epitome Ulpiani 19.1; Vat. Fr. 45.

25. In iure cessio, which in any event is cumbersome, is unlikely to have existed so early: see, e.g., A. Watson, The Law of Property in the Later Roman Republic, Oxford, 1968, 93 and especially n.1.

26. G.2.19; cf. W.W. Buckland, Textbook of Roman Law, 3rd edn. by P. Stein, Cambridge, 1963, $226 \mathrm{ff}$. 
27. For the extensive literature, see Diósdi, Ownership, $109 \mathrm{ff}$.

28. Festus, s.v. viae; Tab. 7.7.

29. Diósdi, Ownership, 114.

30. D.8.3.8; Tab. 7.6.

31. Diósdi, Ownership, 114.

32. For the argument, see A. Watson, The Law of Obligations in the Later Roman Republic, Oxford, 1965, 72 ff.; cf. M. Kaser, Das römische Privatrecht I, Munich, 1955, 460.

33. For the argument see A. Watson, Rome of the XII Tables in the Later Roman Republic, Princeton, 1975, 57.

34. Epitome Ulpiani 11.14; cf. D.50.16.53pr. Rather different versions appear in Cicero, De inventione 2.50, 148 (cf. Rhetorica ad Herennium 1.13.23) and G.2.224 (cf. D.50.16.120). For the argument establishing Ulpian's as the original version, see Watson, XII Tables, 52.

35. See Watson, XII Tables, 52 for the full argument.

36. See Watson, XII Tables, 64 for the argument.

37. Privatrecht I, 108 and the authors he cites. Against the notion of divided ownership, see above all Diósdi, Ownership, $121 \mathrm{ff}$; and Watson, XII Tables, 125 ff. Most recently, Kaser defended his view of relative ownership and divided ownership in 'Relatives Eigentum', 102 Zeitschrift der Savigny-Stiftung, Rom. Abt. (1985), 1 ff. P. Birks, 'The Roman Law Concept of Dominium and the Idea of Absolute Ownership', [1985] Acta Juridica, $1 \mathrm{ff}$., says nothing apropos.

38. Cf. G.1.123; Boethius, II in Topica Ciceronis 3.14; Servius, In Vergilii Georgica 1.31; Isidorus, Etymologiae 5.24; Nonius Marcellus, s.v. nubentes.

39. Nexum itself may, but need not, be an opportunistic use of mancipatio and as such will not be dealt with here, but see Watson, XII Tables, $111 \mathrm{ff}$.

40. For the argument, see Watson, XII Tables, $118 \mathrm{f}$. The provision involved mancipatio (or no opportunistic use of the provision could have been made for mancipatio), but no real sales (or the son would not have returned to the potestasof the father).

41. See, e.g., Buckland, Textbook, 165.

42. See, e.g., G.1.115; 2.112; Cicero, Topica, 4.18; A. Watson, The Law of Persons in the Later Roman Republic, Oxford, 1967, 152 ff.

43. This talk in honour of Andrew Lewis' Professorship of Comparative Legal History at University College London derives very directly from my books, Authority of Law; and Law, Stockholm, 2003, 75 ff., and Legal History and a Common Law for Europe, Stockholm, 2001, $64 \mathrm{ff}$. I feel no shame in this self-plagiarism. I believe most of the readers of this paper will have no access to my Swedish books. 
Copyright of Journal of Legal History is the property of Frank Cass \& Company Ltd. and its content may not be copied or emailed to multiple sites or posted to a listserv without the copyright holder's express written permission. However, users may print, download, or email articles for individual use. 